\title{
OESTRUS, LH, OVULATION AND FERTILITY IN BEEF HEIFERS*
}

\author{
R. K. CHRISTENSON, $\uparrow$ S. E. ECHTERNKAMP $\ddagger$ \\ AND D. B. LASTER $\ddagger$ \\ University of Nebraska, and U.S. Department of Agriculture, \\ Clay Center, Nebraska 68933, U.S.A.
}

\section{(Received 18th November 1974)}

The pregnancy rate resulting from matings at a single oestrus in beef cattle averages $70 \%$ for natural mating (Turman, Laster, Renbarger \& Stephens, 1971 ) and $60 \%$ for artificial insemination (Laster, Glimp \& Gregory, 1972). The sources and causes of low pregnancy rates have not been defined, but might include variation in time of ovulation relative to deposition of spermatozoa in the female reproductive tract, fertilization failure, ovum transport, abnormal ova and blastocyst development, and implantation failure. The interval from onset of oestrus to ovulation in dairy cattle has been reported to average $29 \pm 6 \mathrm{hr}$ with a range from 16 to $42 \mathrm{hr}$ (Swanson \& Hafs, 1971). Such a large interval could account for a high percentage of the losses.

This study included two experiments. The purpose of Exp. 1 was to determine the relationship of the onset of standing oestrus, preovulatory $\mathrm{LH}$ surge and time of ovulation in beef heifers. The purpose of Exp. 2 was to examine the normality of ovum and blastocyst development within the first 15 days after mating.

Twenty-nine yearling beef heifers were assigned to three groups after observation of at least one normal oestrous cycle. Oestrus was checked continuously with bulls and the onset of standing oestrus was recorded when a heifer was first mounted and mated by a bull. Heifers were mated by at least two fertile bulls. The thirteen heifers in Group 1 were bled at 6 -hr intervals, beginning 1 day before expected oestrus and continuing to $30 \mathrm{hr}$ after the onset of oestrus. Blood samples were collected from the eight heifers in Group 2 and the eight in Group 3, beginning at the onset of oestrus and then at 3-hr intervals for the next 12 to $15 \mathrm{hr}$. A final blood sample was obtained at the time of laparotomy/hysterectomy.

Group 1 heifers were subjected to laparotomy 28 to $30 \mathrm{hr}$ after the onset of oestrus; in Group-2 heifers, laparotomy was performed $26 \mathrm{hr}$ after onset of oestrus and, if ovulation had not occurred, a second laparotomy was performed $4 \mathrm{hr}$ later or $30 \mathrm{hr}$ after onset of oestrus. Laparotomy of Group-3 heifers took place $30 \mathrm{hr}$ after onset of oestrus and again at $36 \mathrm{hr}$ if ovulation had not occurred by the time of the first laparotomy.

* Published as Paper Number 3889, Journal Series, Nebraska Agricultural Experiment Station, Lincoln.

$\dagger$ Department of Animal Science, University of Nebraska, U.S. Meat Animal Research Center.

$\ddagger$ U.S. Meat Animal Research Center, Agricultural Research Service. 
At laparotomy, the ovaries were observed through a paralumbar incision. In heifers which had ovulated, the ovary containing the corpus hemorrhagicum, the ipsilateral oviduct and the ipsilateral uterine horn were removed. The oviducts were flushed with physiological saline solution to recover the ova which were then prepared as whole mounts (Chang, 1952), fixed in $25 \%$ acetic-alcohol and stained with $1 \%$ aceto-orcein for examination by phasecontrast microscopy.

Blood was collected from the jugular vein into heparinized syringes, refrigerated immediately, and centrifuged. The plasma was stored at $-20^{\circ} \mathrm{C}$. For analysis, plasma LH was quantified by a double antibody radioimmunoassay as described by Niswender, Reichert, Midgley \& Nalbandov (1969).

Ovum cleavage and blastocyst development were studied in seventy-nine additional cyclic yearling heifers. Oestrus was checked twice daily and heifers were mated to at least two fertile bulls. The day of oestrus was designated

Table 1. Onset of standing oestrus, preovulatory $\mathrm{LH}$ peak and ovulation in beef heifers

\begin{tabular}{|c|c|c|c|c|}
\hline \multirow[b]{2}{*}{ Group } & \multirow[b]{2}{*}{$\begin{array}{l}\text { Noo. of } \\
\text { heifers }\end{array}$} & \multicolumn{3}{|c|}{ Interval $(h r)^{*}$} \\
\hline & & $\begin{array}{l}\text { Oestrus } \\
\text { to LH }\end{array}$ & $\begin{array}{c}\text { LH to } \\
\text { ovulation }\end{array}$ & $\begin{array}{c}\text { Oestrus to } \\
\text { ovulation }\end{array}$ \\
\hline $\begin{array}{l}1 \\
2 \text { and } 3\end{array}$ & $\begin{array}{r}5 \\
16\end{array}$ & $\begin{array}{l}0.6 \pm 2.7 \\
3.5 \pm 0.7\end{array}$ & $\begin{array}{l}30 \cdot 8 \pm 1 \cdot 4 \\
28 \cdot 0 \pm 0.7\end{array}$ & $\begin{array}{l}31.4 \pm 1.4 \\
31 \cdot 3 \pm 0.7\end{array}$ \\
\hline Combined & 21 & $2 \cdot 8 \pm 0.8$ & $28.7 \pm 0.7$ & $31.3 \pm 0.6$ \\
\hline
\end{tabular}

* Mean \pm S.E.M.

Day 0 and heifers were slaughtered at 2, 3,6, 12, and 15 days after mating. The reproductive tracts were flushed with physiological saline to recover ova and blastocysts which were observed under light microscopy; ova were fixed, stained and examined under phase-contrast microscopy.

In Exp. 1, the estimated mean interval \pm S.E.M. was $31.3 \pm 0.6 \mathrm{hr}$ from onset of oestrus to ovulation (Table 1). Between 26 and $30 \mathrm{hr}$ after onset of oestrus, $71 \%$ of the heifers ovulated and $24 \%$ ovulated between 30 and 36 $\mathrm{hr}$ after onset of oestrus. One heifer ( $5 \%$ ) had not ovulated $36 \mathrm{hr}$ after onset of oestrus.

Serum LH values began to increase before the onset of oestrus and reached a mean preovulatory $\mathrm{LH}$ peak value of $67 \pm 8 \mathrm{ng} / \mathrm{ml}$. Approximately $9 \mathrm{hr}$ after the peak LH surge, serum values had returned to baseline values of $2 \mathrm{ng} / \mathrm{ml}$ or less.

The interval from the onset of oestrus to the $\mathbf{L H}$ peak was $2.7 \mathrm{hr}$ longer for the heifers ovulating between 30 and $36 \mathrm{hr}$ after onset of oestrus than in heifers ovulating 26 to $30 \mathrm{hr}$. The mean interval from peak LH surge to ovulation was $1 \mathrm{hr}$ longer for the former heifers than the mean for all heifers.

Oestrus was detected in only five of the heifers in Group 1. The remaining eight heifers in this group were not detected in oestrus by Day 25, but rectal palpation indicated that seven of the eight had ovulated. Initiation of blood 

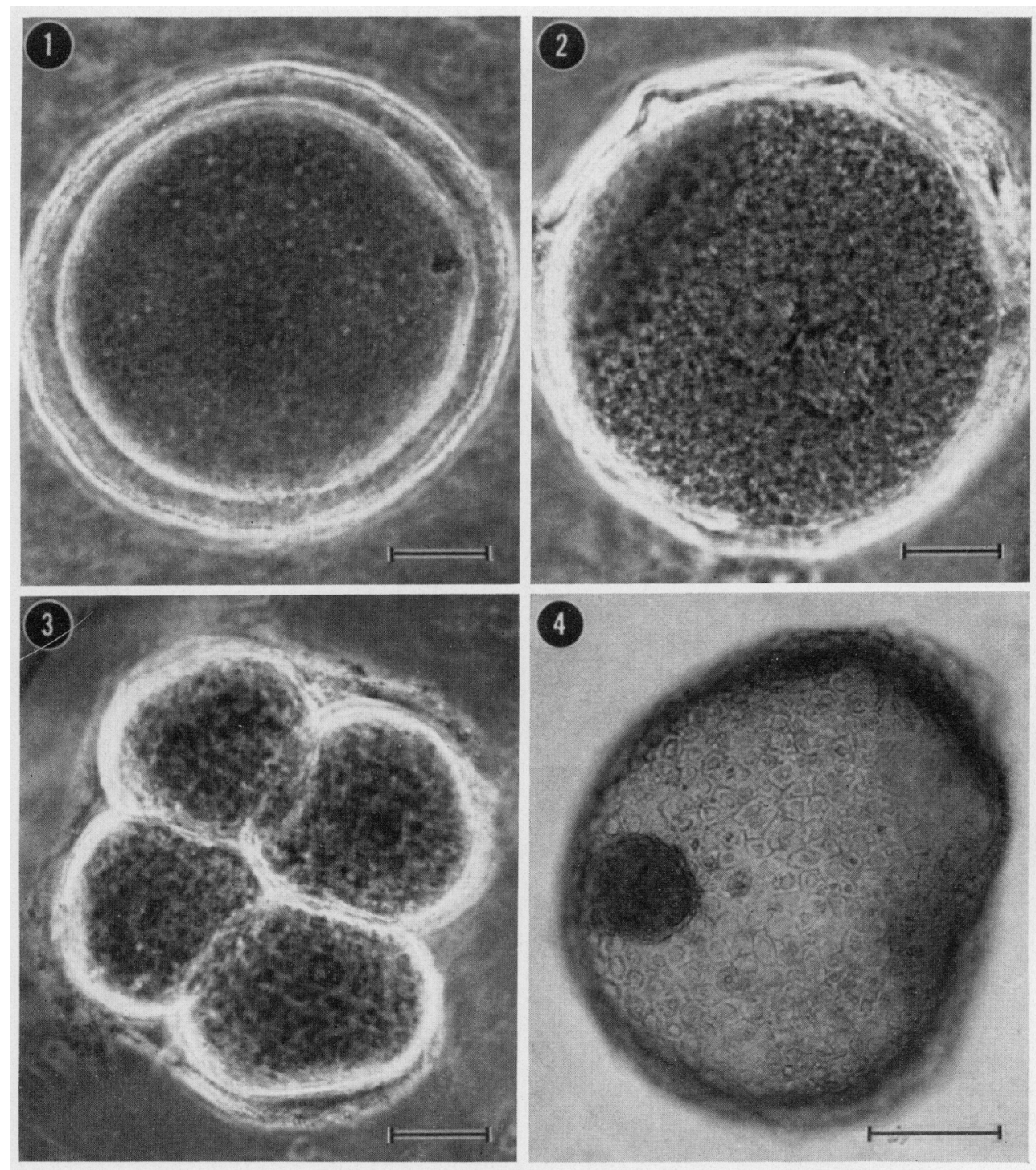

Examples of cow eggs and a blastocyst at 1)ays 2. 3 and 12 alier mating. All figures are phase-contrast plotomicrographs.

lis. 1. Lnfertilized ovum recorered on Day 3. chromatin deaty visible at metaphase II. Scale bar $=30 \mu \mathrm{m}$.

Fis. 2. Fertilized ovum recoreded on Day 2. Both pronuclet visible at syngamy. Scale bas' $=30 \mu \mathrm{m}$.

Fas. 3. Fourecell zygote recorered on Day 3, showing a nucleas per blastomere. Scale bar $=30 \mathrm{~mm}$.

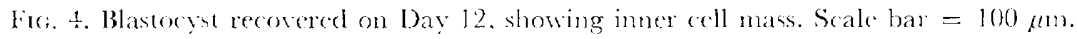


sampling immediately after the onset of oestrus (Groups 2 and 3 ) had no effect on expression of oestrus.

Ovum recovery was 100\% for heifers in Group 1 and $75 \%$ for those in Group 3. No ova were recovered from Group-2 heifers. When laparotomy was performed at $26 \mathrm{hr}$, none of these heifers had ovulated; ovum recovery was attempted again at $30 \mathrm{hr}$ at the time of the second laparotomy. Manipulation of the infundibulum in order to examine the ovary for the presence of a corpus haemorrhagicum or preovulatory follicle at the first laparotomy probably contributed to the inability to recover ova in these heifers at the second laparotomy. Of all ova recovered in Exp. 1, 55\% were classified as fertilized from the presence of first and second polar bodies. Fertilization rates would most likely have been improved if the interval from ovulation to hysterectomy had been longer.

In Exp. 2, the average ovum recovery for the twenty-seven heifers killed on Days 2 and 3 after mating was $73.2 \%$ (Table 2). This is similar to recovery rates reported by Bellows \& Short (1972) and Laster (1973). The fate of unrecovered ova on Days 2 and 3 and the contribution of these ova to the low conception rate is not known.

Table 2. Conceptus recovery and fertility in beef heifers

\begin{tabular}{cccccccl}
\hline & & \multicolumn{8}{c}{ Conceptus data } \\
\cline { 3 - 8 } Day after & $\begin{array}{c}\text { No. of } \\
\text { mating }\end{array}$ & $\begin{array}{c}\text { Recovered } \\
\text { heifers }\end{array}$ & $\begin{array}{c}\text { Normal } \\
(\text { No. })\end{array}$ & $(\%)$ & $\begin{array}{c}\text { Abnormal } \\
(\text { No. })\end{array}$ & \multicolumn{1}{c}{$\begin{array}{c}\text { Stage of } \\
\text { development }\end{array}$} \\
\hline 2 & 10 & 7 & 70 & 5 & 71 & $2 *$ & Pronucleus to two-cell \\
3 & 17 & 13 & 77 & 11 & 85 & $2 *$ & Four- to eight-cell \\
6 & 5 & 3 & 60 & 3 & 100 & 0 & > Sixteen-cell \\
12 & 24 & 13 & 54 & 13 & 92 & 1 & Blastocyst \\
15 & 23 & 17 & 74 & 17 & 100 & 0 & Blastocyst \\
\hline
\end{tabular}

* Unfertilized ova.

Of the ova recovered from heifers on Days 2 and 3 after mating, $80 \%$ were fertilized. The four unfertilized ova recovered on Days 2 and 3 were at metaphase II (Pl. 1, Fig. 1) and only one of the four ova had spermatozoa on the zona pellucida. The stage of zygote development ranged from pronuclear to two cells on Day 2 and from four to eight cells on Day 3 (Pl. 1, Figs 2 and 3 ).

Zygotes recovered on Day 6 were at the morula stage of development and appeared normal. One zygote recovered on Day 12 was classified as abnormal because it had only developed to the morula stage instead of to a free-floating blastocyst. The remaining blastocysts recovered on Day 12 (PI. 1, Fig. 4) and Day 15 appeared normal.

The results of this study indicate that variation from onset of oestrus to ovulation does not appear to be as large among animals as indicated by previous studies. Although variation in time of ovulation relative to mating may be a source of pregnancy loss, it does not appear to account for a very high percentage of the losses. The fate of unrecovered ova and the significance of these ova to pregnancy is not known. Observations on cleavage and blastocyst 
development indicate that fertilization failure and abnormal conceptus development account for some of the pregnancy losses in beef cattle.

\section{REFERENCES}

Bellows, R. A. \& Short, R. E. (1972) Superovulation and multiple births in beef cattle. F. Anim. Sci. 34, Suppl. 1, 67-77.

Chang, M. C. (1952) Fertilizability of rabbit ova and the effects of temperature in vitro on their subsequent fertilization and activation in vivo. F. exp. Zool. 121, 351-382.

LASTER, D. B. (1973) Ovulation, fertility and prenatal mortality in heifers treated with PMSG or porcine FSH. F. Reprod. Fert. 33, 275-282.

LASTER, D. B., Glimp, H. A. \& GreGORY, K. E. (1972) Age and weight at puberty and conception in different breeds and breed-crosses of beef heifers. F. Anim. Sci. 34, 1031-1036.

Niswender, G. D., Reichert, L. E., Jr, Midgley, A. R., JR \& Nalbandov, A. V. (1969) Radioimmunoassay for bovine and ovine luteinizing hormone. Endocrinology, 84, 1166-1173.

Swanson, L. V. \& HaFs, H. D. (1971) LH and prolactin in blood serum from estrus to ovulation in Holstein heifers. F. Anim. Sci. 33, 1038-1041.

Turman, E. J., Laster, D. B., Renbarger, R. E. \& Stephens, D. F. (1972) Multiple births in beef cows treated with equine gonadotropin (PMS) and chorionic gonadotropin (HCG). F. Anim. Sci. 32, 962-967. 